www.jmscr.igmpublication.org

Impact Factor (SJIF): 6.379

Index Copernicus Value: 71.58

ISSN (e)-2347-176x ISSN (p) 2455-0450

crossref DOI: https://dx.doi.org/10.18535/jmscr/v6i6.106

Journal Of Medical Science And Clinical Research

IGM Publication

An Official Publication of IGM Publication

\title{
Hepatitis B Virus Burden in Jammu (J\&K): A Maiden Study
}

\author{
Authors \\ Dr Shashi S Sharma ${ }^{1}$, Dr Konika Razdan ${ }^{2}$, Mamta Sharma ${ }^{3}$, Sonali Sharma ${ }^{4}$ \\ Sourabh S Sambyal ${ }^{5}$ \\ ${ }^{1}$ Professor, PI and Nodal Officer VRDL, Dept of Microbiology, GMC Jammu \\ ${ }^{2}$ Research Scientist I (Non Medical), VRDL, Dept of Microbiology, GMC Jammu. \\ ${ }^{3,4}$ Lab. Technicians, VRDL, Dept of Microbiology, GMC Jammu. \\ ${ }^{5}$ Research Assistant, VRDL, Dept of Microbiology, GMC Jammu \\ Corresponding Author \\ Dr Shashi S Sharma \\ Prof, PI and Nodal Officer, VRDL Dept. of Microbiology, GMC Jammu, India
}

Email:vrdlgmc@gmail.com

\begin{abstract}
Background: Sero-surveillance of Hepatitis B virus infection in the Jammu province of J and K, India.

Objectives: The study was envisaged with the objective to (1) Study the Hepatitis B burden in the Jammu province (2) To further formulate the regional management policy, study the Genotypes and conduct Phylogenetic analysis based on this study.

Methods: Referred patient's blood specimens were collected for HBsAg ELISA and tested. The test results were shared with both patients and the clinicians.

Results: The prospective study was conducted from January 2014 to December 2016 wherein a total of 27,703 ELISA tests were performed and 678 patients were positive (2.44\%). Male (64.60\%) preponderance was observed over females (35.39\%) with an overall positivity of $1.58 \%$ and $0.86 \%$ respectively. Highest prevalence of $54.71 \%$ was observed in the age group of 41-60 years followed by a prevalence of $29.20 \%$ in 19 to 40 years, $14.45 \%$ in $61-80$ and $1.44 \%$ in the age group above 80 . Of the 27,703 samples screened 449 (1.62\%) were from the HIV-ART clinic and 7(1.55\%) were found to be co-infected.

Conclusion: A seroprevalence of $2.44 \%$ was reported with male predominance $(58.35 \%)$ with the maximum number of affected population being in the age group of 41-60 years (54.71\%). The co prevalence of $\mathrm{HBs} \mathrm{Ag}$ and HIV was found to be $1.55 \%$.
\end{abstract}

Keywords: Hepatitis B virus, HBsAg ELISA, seroprevalence, preponderance, co- infection.

\section{Introduction}

Hepatitis B is a potentially debilitating and deadly disease caused by Hepatitis B virus (HBV) with an annual global mortality of 1.34 million per year surpassing both HIV and Malaria ${ }^{(1)}$. According to WHO, of the estimated 257 million people infected with $\mathrm{HBV}$, about $89 \%$ are oblivion of their carrier status because of the absence of symptoms ${ }^{(1)}$ thereby creating a "silent epidemic". Based on the global prevalence of chronic HBV infection the countries are divided into High $(\geq 8 \%)$, Moderate prevalence $(2-8 \%)$ and Low prevalence $(<2 \%)$ zones. HBV induces an array of liver diseases ranging from acute or fulminant 
hepatitis to liver cirrhosis (LC) and hepatocellular carcinoma $(\mathrm{HCC})^{(2)}$. HBV, a double-stranded DNA virus belongs to the hepadnaviridae family and is transmitted by either percutaneous route or contact of mucous membrane with infected blood or other body fluids with primary routes of transmission being perinatal, early childhood exposure, sexual contact and percutaneous exposure to blood or body fluids ${ }^{(3)}$. It has an incubation period ranging from 40 to 160 days (average 60-90) and is self-limited in most adult patients with acute infection. About 1-2\% of patient's progress to fulminant hepatic failure, and some develop chronic infection ${ }^{(4)}$. The rate of progression from acute to chronic HBV infection is reported to be about $90 \%$ in newborns and 5$10 \%$ in adults ${ }^{(5)}$. During the course of acute infection, high levels of Hepatitis B surface antigen (HBsAg), Hepatitis B e antigen ( $\mathrm{HBeAg}$ ) and Anti $\mathrm{HBc}$ can be detected in the serum ${ }^{(6)}$. The persistence of HBsAg for more than 6 months from its first discovery signifies chronic Hepatitis $\mathrm{B}$ (CHB) infection and varies with age at which the infection is acquired, the risk being lowest in adults $(5 \%)$ and greatest in neonates $(90 \%)$ born to $\mathrm{HBsAg}$ positive mothers ${ }^{(3)}$. $\mathrm{HBV}$ is differentiated into eight well known genotypes designated as A-H and two new genotypes I and J, have also been introduced ${ }^{(7)}$.

India has one-fifth of the world's population and accounts for a large proportion of the total HBV burden of the world with an estimated number of around 40 million HBV carriers and harbors about $10-15 \%$ of the entire pool of the world ${ }^{(8)}$. With an average carrier rate of $3.78 \%$ India has an intermediate range of $\mathrm{HBV}$ endemicity ${ }^{(9)}$ with a prevalence reported in Northern India, West Bengal, Tripura and Tamil Nadu of $(2.1 \%)^{(10)}$, $(2.97 \%)^{(11)},(3.6 \%)$ and $(5.7 \%){ }^{(12)}$ respectively at community level. In Kashmiri population, the prevalence of HBV is $0.56 \%-1.1 \%{ }^{(13)}$ while in Ladakhi tribal population a high prevalence of $7.86 \%$ has been reported ${ }^{(14)}$. This raises the possibility of unreported pockets of $\mathrm{HBV}$ in Jammu and Kashmir and a need for a meticulous regional epidemiological survey, which is lacking due to inadequate study reports from different regions. Thus, it is vital to study and estimate the prevalence of HBV in different parts of the state and to find hotspots of HBV endemic regions. The district of Jammu has never ever been studied for HBV sero-prevalence. Furthermore, being in the neighborhood of the state of Punjab with a reported prevalence of about $17.02 \%^{(15)}$ due to established Intra venous (IV) drug abuse it is important to estimate the prevalence of $\mathrm{HBV}$ in Jammu District. Public-health surveillance is a vital means of deterrence and management of infectious and chronic diseases and the medical execution of affected population. Surveillance data provides an insight into the magnitude of health problem, natural history of the disease, timely epidemic detection, documentation, distribution and spread of a health event or disease, evaluation, prevention and control measures and to aid in public health planning ${ }^{(16)}$. Epidemiological data on $\mathrm{HBV}$ infection and a standardized surveillance is important for development of strategies to tackle the spread of the disease, reduce morbidity and mortality through therapeutics and public policy, appropriate resource distribution, and programmatic and educational interventions.

\section{Material and Methods}

Study Population: The present hospital based study was conducted from January 2014 to December 2016 amongst the patients attending various departments of Govt. Medical College, Jammu and serum samples were sent to the Viral Research and Diagnostic Lab., Deptt. of Microbiology for HBsAg ELISA. A detailed questionnaire was designed which highlighted age, sex, marital status and family history, area of residence, occupation, lifestyle and past history of travel, disease (if any) and blood transfusion etc. Results were shared with the patients and the concerned clinicians.

Serological testing: The Hbsag ELISA was done using Alere, True LISA ${ }^{\mathrm{TM}}$ test kit for a qualitative 


\section{JMSCR Vol||06||Issue||06||Page 637-646||June}

detection. The kit contains antiHBs pre-coated wells in the microplate. During the first incubation HBsAg in the patients' serum binds to the precoated anti HBs on the well and to the anti HBsAg enzyme conjugate added simultaneously in this sandwich solid phase immunoassay. After incubation all the unbound material is removed by washing and the residual enzyme activity in the wells (which is directly proportional to the HBsAg in patients' serum) is evidenced by incubating with the substrate solution (TMB) in a substrate buffer. After adding the stop solution, results are finally visualized by EIA plate reader (Make: Tekan Infine Pro F200) at the wavelength of 450 $\mathrm{nm}{ }^{(17)}$ and $625 \mathrm{~nm}$ as the reference wavelength. The kit controls and in-house controls were used with every assay for validation and calculation of the cut-off values.

\section{Results}

The prospective study was conducted from January 2014 to December 2016 wherein a total of
27,703 ELISA tests were performed (8995, 9075 and 9633 tests in the years 2014, 2015 and 2016 respectively) [Figure 1]. Of these $249(2.76 \%)$, $216(2.38 \%)$ and $213(2.21 \%)$ samples were found to be positive summing up to a total positivity in 678 patients $(2.44 \%)$ [Figure 2]. Out of the positive patients, $438(64.60 \%)$ were male and $240(35.39 \%)$ were female with an overall positivity of $1.58 \%$ and $0.86 \%$ respectively [Figure 3]. Highest prevalence of $54.71 \%$ (370) was observed in the age group of 41-60 years followed by a prevalence of $29.20 \%$ (198) in 19 to 40 years, $14.45 \%$ (98) in $61-80$ and $1.44 \%$ (11) in the age group above 80 [Figure 4]. Of the total 27,703 samples screened 449 (1.62\%) were from HIV-ART clinic; amongst the HIV positives 262 $(58.35 \%)$ were male and $187(41.6 \%)$ were female. A total of 7 (1.55\%) patients were reported positive for HBsAg from the patients referred from the ART /HIV Clinic which depicted an overall prevalence of $1.55 \%$ only [Fig 5(a) and 5(b)].

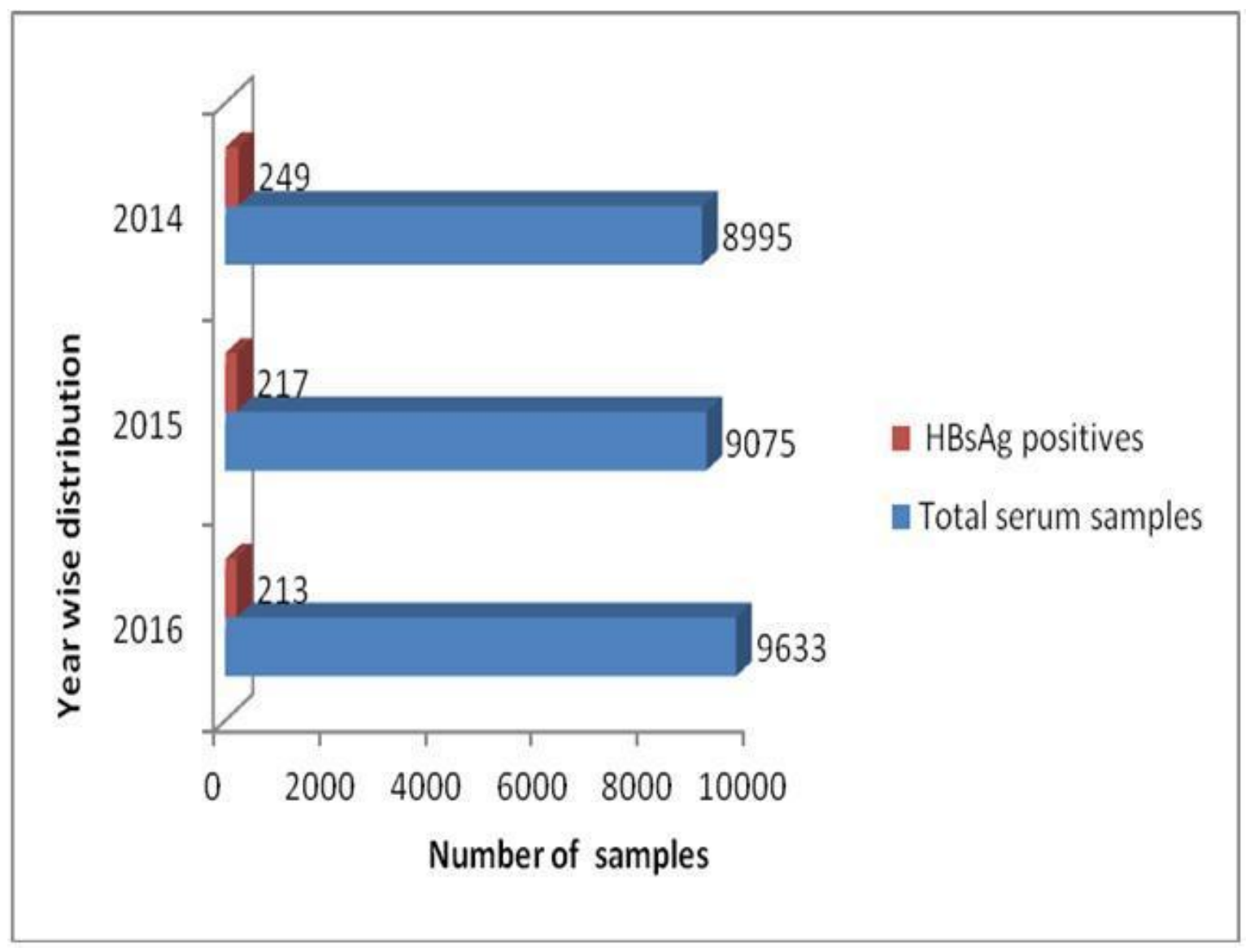

Fig.1: Distribution of samples received and total HBsAg positive samples during the year 2014-2016 


\section{JMSCR Vol||06||Issue||06||Page 637-646||June}

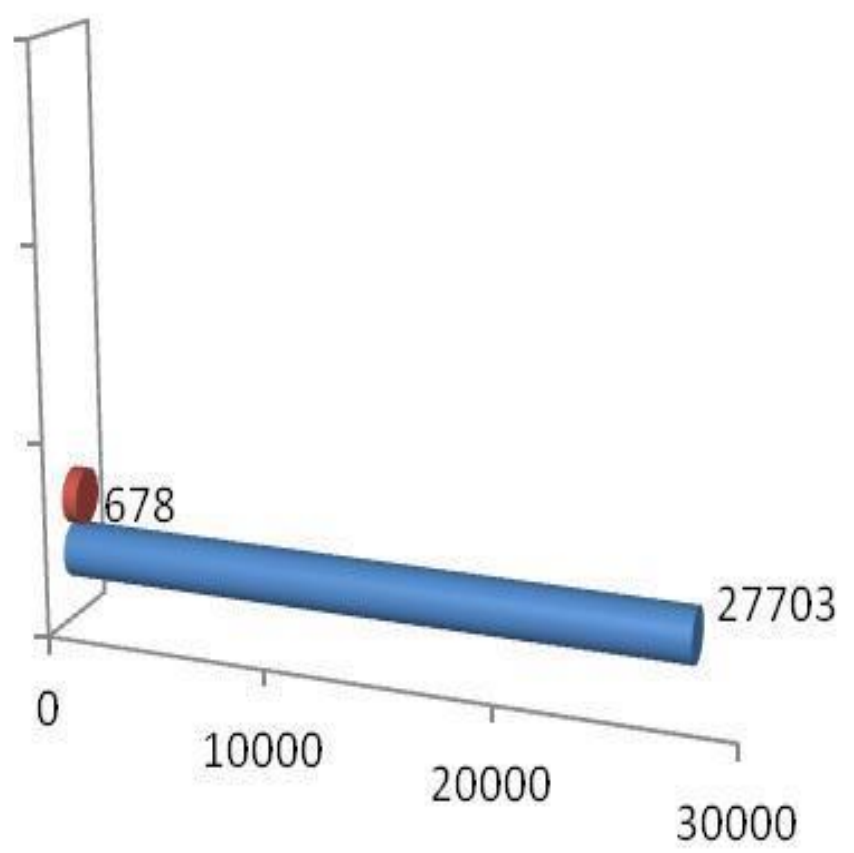

Total positives

- Total samples

Total number of samples and total positives for $\mathrm{HBsAg}$

Fig. 2: Figure depicting total number of samples tested and total number of positive samples.

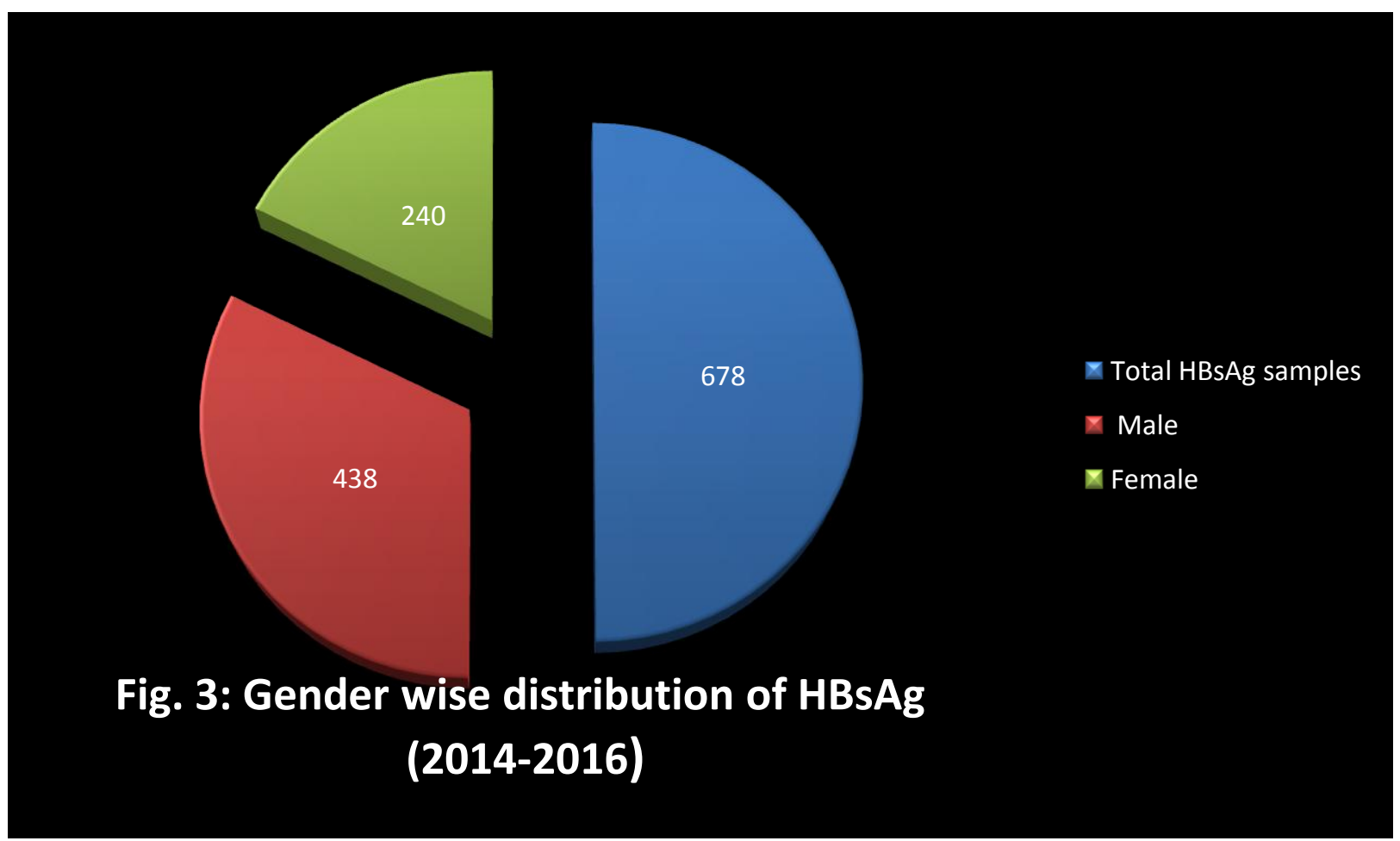

Fig. 3: Gender wise distribution of HBsAg 


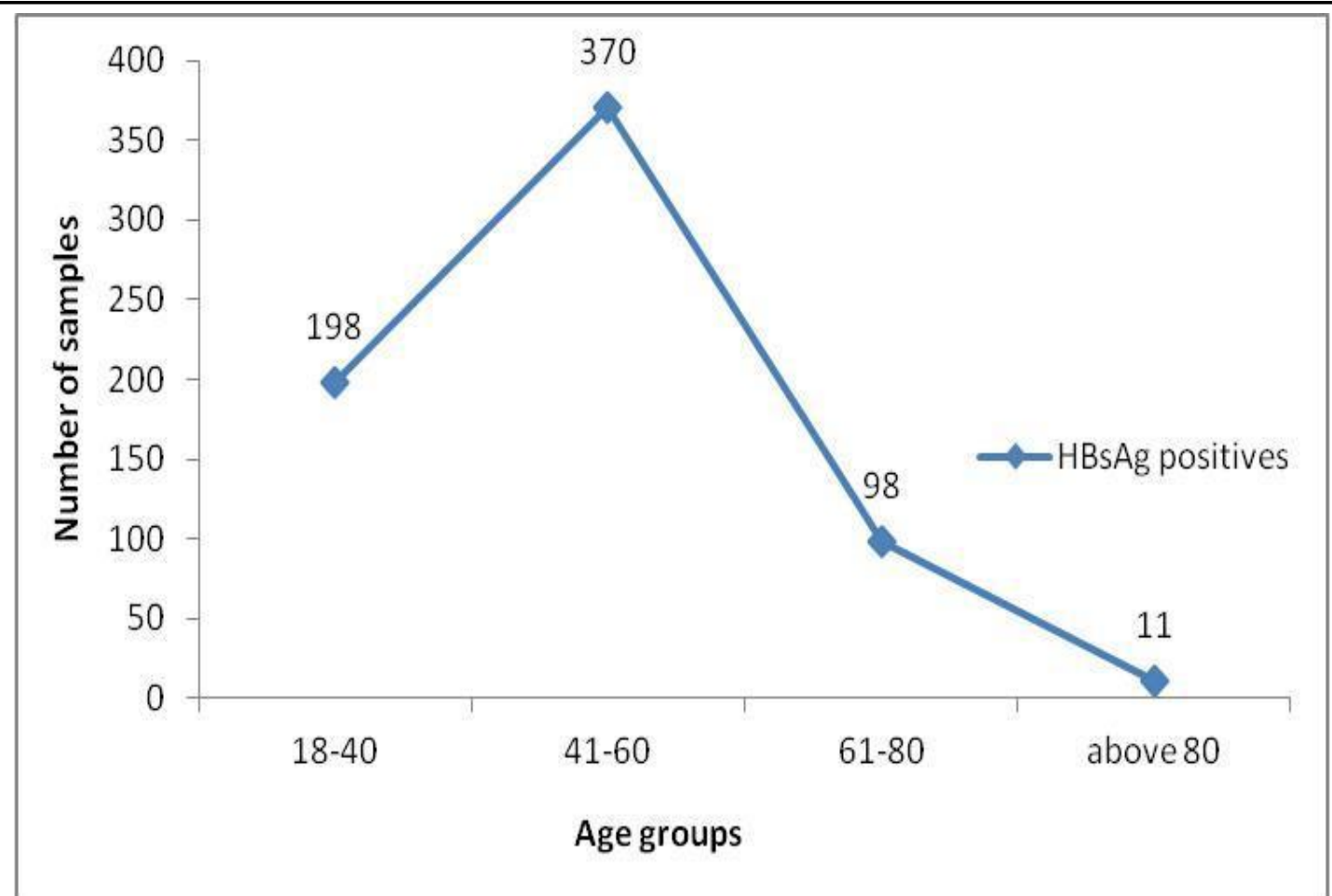

Fig 4: Distribution of HBsAg Positive cases into various age groups.

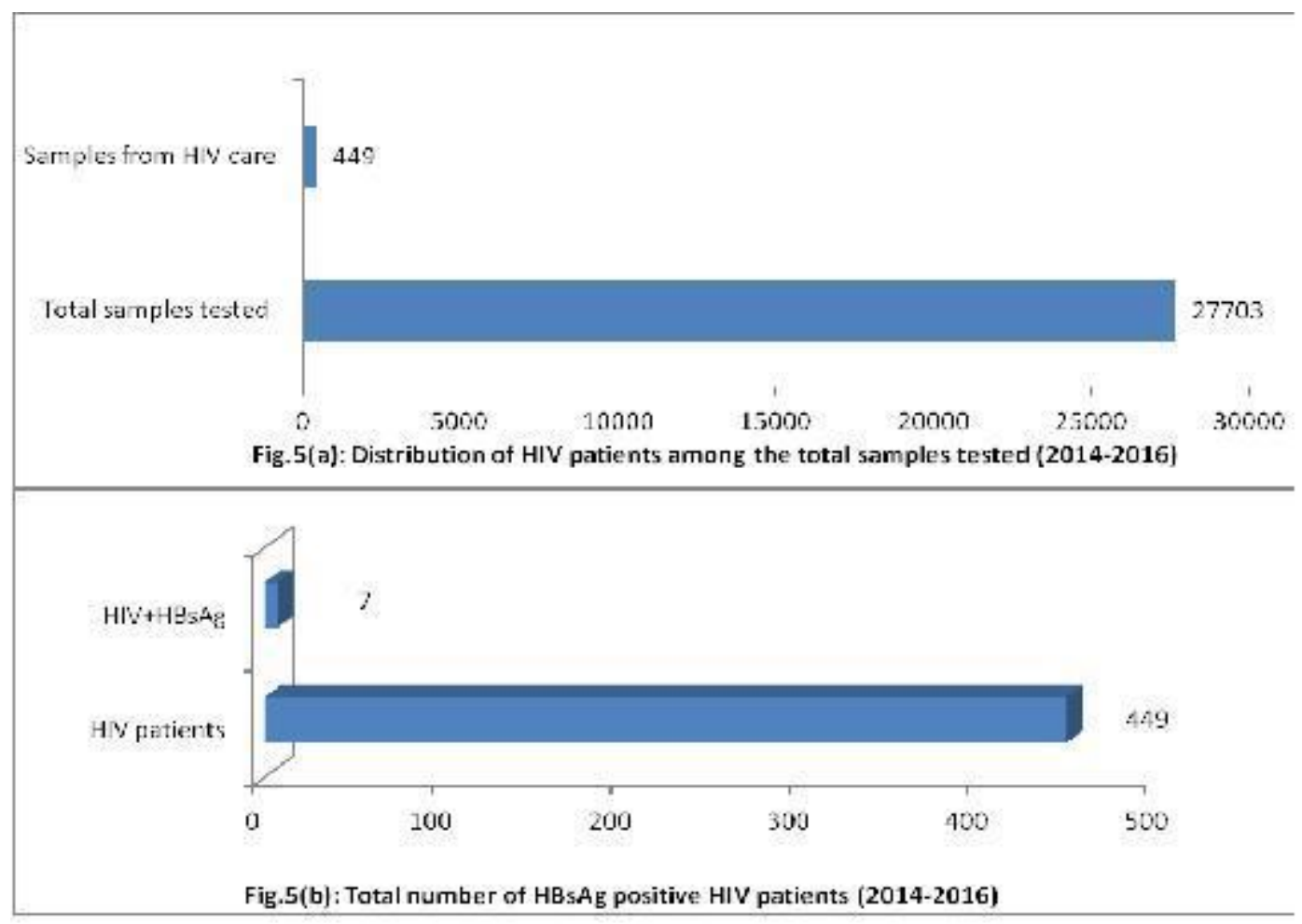

Fig. 5: HIV-HBsAg co -infection profile

\section{Discussion}

HBV, being a debilitating infection remains an imperative health and socioeconomic calamity worldwide despite persistent escalation in its prevention and management. A periodic appraisal of epidemiological data is imperative to better assess and monitor the health status of populations and for preparing more precise future health strategies. In the epidemiological studies conducted across the world the prevalence of HBV infection varies with varied geographical niches, which depend upon complex interaction of 
behavioral, environmental, health and hygiene facilities and factors.

There is a dearth of population-based studies on Hepatitis B from various regions of India and the exact number of affected populace and the estimates are under-reported. In the present study, serological tests were performed to estimate the prevalence of HBV in the population of Jammu region and a prevalence of $2.44 \%$ was reported amongst the patients attending the tertiary care hospital at Jammu. Similarly, a seroprevalence of $2.97 \%, 2.5 \%$ and $1.63 \%$ has been reported from hospitals at West Bengal ${ }^{11}$, Kathmandu ${ }^{(18)}$ and Karnataka $^{(19)}$ respectively. A sero positivity of $1.10 \%$ and $0.58 \%$ was reported amongst the hospital attendees from Warudi in Nashik, ${ }^{(20)}$ and Tumkuru, South India ${ }^{(21)}$. On the contrary, in a retro-prospective study conducted at a hospital in Nepal and a tertiary care hospital at North Western Nigeria seroprevelance of $4.19 \%^{(22)}$ and $9.2 \%^{(23)}$ has been reported. In another pivotal study conducted at a North Indian Hospital from 2005-2013 seroprevelance was found to range from $0.92 \%$ to $1.75 \%{ }^{(24)}$ indicative of consistent infection. In a meta- analysis of 54 studies of HBsAg prevalence in India by Batham et al., a prevalence of $2.4 \%$ and $15.9 \%$ among the non tribal and tribal population respectively was reported $^{(25)}$. Although, when the same study was done using population weight, it was anticipated that the point-prevalence of HBV among nontribal and tribal populations was $3.07 \%$ and $11.85 \%$ respectively with an overall prevalence of $3.70 \%{ }^{(26)}$. According to a WHO report on prevention of $\mathrm{HBV}$ in India, ${ }^{(27)} \mathrm{HBsAg}$ prevalence among general population ranges from $0.1 \%$ to $11.7 \%$, being between $2 \%$ and $8 \%$ in most studies. $^{(28)}$

In our study male preponderance with a seroprevelance of $1.56 \%$ in males and $0.86 \%$ in females was noticed. In a similar study from Puducherry a reported seroprevalence of $1.73 \%$ for HBsAg and male predominance $(2.73 \%)$ over females $(1.09 \%)^{(29)}$ has been reported. A sero prevalence of $1.04 \%$ and $0.58 \%$ respectively for males and females was reported from a population based study in Jaipur ${ }^{(30)}$. In a study from Karnataka a prevalence of $0.65 \%$ and $0.25 \%$ was observed respectively in males and female subjects $^{(31)}$. In a six year long study, seroprevalance of HBsAg was reported to be $12.8 \%$ with the higher prevalence rate in subjects between 21 to 30 years of age and male preponderance ${ }^{(33)}$ (Male:Female $=2.8: 1$ ). On the contrary, in a hospital based study from Manipal, a seroprevelance of $35.3 \%$ in males and $19.3 \%$ in females was reported ${ }^{(31)}$.

Similar results were reported in many other studies concerning $\mathrm{HBV}$ infection from other countries. In North West Ethiopia $4.9 \%$ in males and $3.3 \%$ in females ${ }^{(34)}$ whereas $38.2 \%$ males and $31.8 \%$ females at a public hospital at Adis Ababa Ethiopia $^{(35)}$ have been reported. In Keffi, Nigeria $24.1 \%$ in males and $9.55 \%$ in females ${ }^{(36)}$ while from Ibandan, Southwestern Nigeria $10.2 \%$ in males and $5.95 \%$ in females ${ }^{(37)}$ has been reported. This general male preponderance is attributed to the risky sexual practices to which men are exposed. More recently, studies were conducted to study this gender disparity further and it was concluded that estrogen or estrogenic compounds had a therapeutic effect on induced Hepatocellular carcinoma in male mice thereby providing a new imminent into understanding the basis behind male predominance ${ }^{(38)}$.

In this maiden study from Jammu, the maximum sero-prevalence of HBsAg (54.71\%) was observed in the age group of 41-60 years. Similar to our study, a maximum seropositivity was reported in the age group of 41-60 (41.6\%) years as compared to the younger age group from south India $^{(21)}$ also. In the neighbouring country of Nepal the highest prevalence $(30 \%)$ of $\mathrm{HBsAg}$ was reported among the age group of 51-60 years $^{(22)}$ and depicted as the most susceptible group. In yet another study a maximum seroprevalence $(53.63 \%$ and $50.0 \%$ ) was reported in the age group of $30-40$ and $40-50$ respectively ${ }^{(39)}$. In contrast to our observation maximum prevalence $(61.53 \%)$ in economically 
productive age group (21-40 years) in a hospital at Karnataka $^{(40)}$ was reported. Realizing the dangers of Hepatitis B infection in particular, Hepatitis B vaccination was started in India under a pilot project in the year 2004. Thereafter, in 2007-08 it was expanded later under the Universal Immunization Programme. The noteworthy union of HBV markers and older ages might be due to the greater number of years of potential exposure, a lack of adult $\mathrm{HB}$ vaccination programme and the lack of awareness of HBV infection in the past ${ }^{(42)}$. Amongst 27,703 samples screened in the present study, $449(1.6 \%)$ were from HIV testing laboratory and 7/449 (1.55\%) patients were found to be HBsAg positive. Co-Infection with three common chronic viral infections i.e., Hepatitis B (HBV), Hepatitis C (HCV) and Human immunodeficiency virus (HIV) is frequent due to similar routes of transmission and although, there is some data on the prevalence of these infections in the common population of India, ${ }^{(42)}$ there is an inadequate information on co-infection ${ }^{(43)}$. In a study from Maharashtra ${ }^{(43)}$ among 110 HIV seropositive patients, $30.4 \%$ were positive for HBV while a study from Chennai, ${ }^{(44)}$ reported a seroprevalence of HIV/HBV coinfection of $4 \%$. On the contrary a study from Manipur, reported a very high prevalence of HBV (100\%) infection amongst HIV seropositive intravenous drug users (45) which is in total contrast to our study wherein a $1.55 \%$ prevalence of HIV and HBV coinfection exists. This is one of the significant results from our study as the co-prevalence of HIV and HBsAg in our state was much less than others, which might be ascribed to very squat IV drug abuse in this part of state and better management of the disease.

The findings in the present study reflect the seropositive patient population served by our hospital and indirectly estimate the disease burden in the community and provide a good reference for future studies. The current study is a maiden of its kind from Jammu region of $\mathrm{J}$ and $\mathrm{K}$, India shedding light on the sero prevalence of HBsAg in our population. In the present study, a total seroprevalence of $2.44 \%$ was reported with male predominance $(58.35 \%)$ with a maximum number of affected population being in the age group of 41-60 years $(54.71 \%)$. The co prevalence of HBsAg and HIV was also depicted and was found to be insignificant (1.55\%) as compared to other studies.

The current statistics lack the inputs from HCWs, neonates and antenatal women. Although still not adequate but this study will prove to be a milestone in framing the disease burden of hepatitis B in this region and also for projecting the cost accrued in immunization of the population and drafting policies to prevent and contain the spread. Further, studies on the prevalent regional genotypes and phylogenetic studies and association of the genotypes and disease progression are in line and will help in alleviating the disease in near future.

\section{References}

1. Global burden of Disease 2016: The Lancet: September 16, 2017

2. Michitaka K, Nishiguchi S, Aoyagi $Y$, Hiasa Y, Tokumoto Y, Onji M. Etiology of liver cirrihosis in Japan a Nationwide survey. J Gastroenterol. 2010; 45: 86-4.

3. Aspinall EJ, Hawkins G, Fraser A, Hutchinson SJ, Goldberg D. Hepatitis B prevention, diagnosis, treatment and care: a review. Occup Med. 2011;61:531-540.

4. Yim HJ, Lok AS. Natural history of chronic hepatitis B virus infection: what we knew in 1981 and what we know in 2005. Hepatol. 2006; 43:173-81.

5. Hoofnagle JH, Doo E, Liang TJ, Fleischer R, Lok ASF. Management of hepatitis B: summary of a clinical research workshop. Hepato.1 2007; 45:1056-75.

6. EMI Guidelines - Appendix 21 Hepatitis B virus: epidemiology and transmission risks (updated May 2016)

7. Raimondi S, Maisonneuve P, Bruno S et al. Is response to antiviral treatment 
influenced by hepatitis B virus genotype? J Hepatol. 2010; 52:441-449.

8. Dutta S. An overview of molecular epidemiology of hepatitis B virus (HBV) in India. Virology J. 2008;5:156.

9. Yadav K, Biswas D, Baruah P, Borkakoty B, Mahanta J. Hepatitis B Endemicity in Some Parts of Arunachal Pradesh, Northeast India . Indian J Community Med. [Epub ahead of print] [cited 2018 Mar 23]. Available from: http://www.ijcm.org.in/preprintarticle.asp? id $=173502$.

10. Singh H, Aggarwal R, Singh RL, Naik SR, Naik S. Frequency of infection by hepatitis $B$ virus and its surface mutants in a northern Indian population. Ind $\mathbf{J}$ Gastroenterol. 2003;22 (4):132-137.

11. Chowdhury A, Santra A, Chakravorty R, Banerji A, Pal S, Dhali GK, Datta S, Banerji S, Manna B, Chowdhury SR, Bhattacharya SK, Mazumder DG. Community-based epidemiology of hepatitis B virus infection in West Bengal, India: prevalence of hepatitis B e antigennegative infection and associated viral variants J Gastroenterol Hepatol. 2005 Nov; 20:1712-20.

12. Kurien T, Thyagarajan SP, Jeyaseelan L, et al. Hepatitis B Infection in Tamil Nadu, India. Ind J Med Res. 2005;121(5):670675.

13. Sodhi JS, Raja W, Zargar SA, Javid G, Aejaz S, Khan MA, Showkat A, Parveen S, Jan, A, Nisar S, Yattoo GN, Shah A. Screening for Occult and Overt Hepatitis B Virus Infection in Patients of Cancer before Receiving Chemotherapy: Looking Beyond HBsAg Testing. Int.J. Adv. Res. 2015; 3(1):458-465.

14. Wani MI, Rashid A, Tanvir M, Ajaz S. Prevalence of Hepatitis B in Kargil, Ladakh; Community Based study from a Rural area of Jammu and Kashmir. Ann. Int. Med. Dent Res. 2015; 3(5).
15. Chalana H, Kundal T, Malhari AS. Changing Trends in Drug Abuse Patterns and Seroprevalence of HIV, Hepatitis B Surface Antigen, and Hepatitis $\mathrm{C}$ in Substance Abusers Admitted to A Tertiary Hospital in Amritsar, India. Int J High Risk Behav Addict. 2017.

16. Thacker SB. Surveillance. Field Epidemiology. Edited by: Gregg MB. 2002, New York: Oxford University Press, 26-50.

17. Rubin E. Acute and chronic viral hepatitis. Federation Proceedings 1979; 38: 2665-73.

18. Bhatta CP, Thapa B, Rana BB. Seroprevalence of Hepatitis B in Kathmandu Medical College Teaching Hospital. Kathmandu UnivMed J(KUMJ). 2003;1:113-6.

19. Quadri SA, Dadapeer HJ, Arifulla KM, Khan N. Prevalence of Hepatitis B Surface Antigen in hospital based population in Bijapur, Karnataka. Al Ameen J Med Scie. 2013; 6(2):180-182.

20. Hatkar S, Baviskar J, Kotgire S. SeroPrevalence of Hepatitis 'B' Virus Infection: A Teaching Hospital Based Study. Int.J.Curr.Microbiol.App.Sci. 2016; 5(12): 524-52.

21. Parimala TV. A Retrospective Study on Seroprevalence of Hepatitis B Surface Antigen among Patients in a Tertiary Care Hospital, South India. Int. J. Curr. Microbiol. App.Sci. 2016; 5 (11):329-333.

22. Bhatta B, Thapa R, Pant P, Pandeya DR. A Retrospective Hospital Based Study In Kathmandu to Assess the Seroprevalence of Hepatitis B Virus. JMMIHS 2016; 2:3-6

23. Isa I, Aminu M, Abdullahi SA, Sani MA and Akafyi DE. Seroprevelance of hepatitis $b$ virus in a tertiary institution in North Western Nigeria. Afr. J. Microbiol. Res. 2015; 9(3): 171-179.

24. Makroo RN, Hegde V, Chowdhry M, Bhatia A, Rosamma NL. Seroprevalence of infectious markers \& their trends in blood donars in a hospital based blood 
bank in north India. Indian J. Med. Res. 2015; 142: 317-322.

25. Batham A, Narula D, Toteja T, Sreenivas V, Puliyel JM. Sytematic review and metaanalysis of prevalence of hepatitis B in India. Indian Pediatr. 2007; 44:663-74.

26. Batham A, Gupta MA, Rastogi P, Garg S, Sreenivas V, Puliyel JM. Calculating prevalence of hepatitis B in India: using population weights to look for publication bias in conventional meta-analysis. Indian J Pediatr. 2009;76:1247-1257.

27. Prevention of Hepatitis B in India - An Overview. New Delhi: World Health Organization South-East Asia Regional Office; 2002

28. Puri P. Tackling the Hepatitis B Disease Burden in India. J clin exp hepatol. 2014;4:312-319.

29. Balamurugan, Gopal R, Saleem M, Kaviraj M, Shivekar SA, Mangaiyarkarasi T. Prevalence of Hepatitis B Surface Antigen among Patients Attending a Rural Teaching Hospital at Puducherry. Indian J Microbiol Res. 2016; 3 :74-6.

30. Sood S and Malvankar S. Seroprevalence of Hepatitis B Surface Antigen, Antibodies to Hepatitis $\mathrm{C}$ virus and Human immunodeficiency virus in a Hospital Based Population in Jaipur, Rajasthan, Indian J Community Med. 2010; 35(1):165-169.

31. Singh K, Bhat S, Shastry S. Trend in seroprevalence of Hepatitis B virus infection among blood donors of coastal Karnataka. India J Infect Dev Ctries. 2009; 3(5):376-379.

32. Ahmad B, Grover R, Ratho RK, Mahajan RC. Prevalence of hepatitis $B$ virus infection in Chandigarh over a six year period. Trop Gastroenterol. 2001;22:18-9.

33. Dutta S, Shivanand PG, Chatterjee A. Prevalence of hepatitis B surface antigen and antibody among hospital admitted patients in Manipal. Indian J Public Health. 1994; 38: 108-12.

34. Tessema B, Yismaw G, Kassu A et al. Seroprevalence of HIV, HBV, HCV and syphilis infections among blood donors at Gondar University Teaching Hospital, Northwest Ethiopia: declining trends over a period of five years. BMC Infect Dis. 2010; 10(111).

35. Ayele AG, Gebre-Selassie S. Prevalence and Risk Factors of Hepatitis B and Hepatitis C Virus Infections among Patients with Chronic Liver Diseases in Public Hospitals in Addis Ababa, Ethiopia ISRN ISRN Trop Med. 2013; Article ID 563821, http://dx.doi.org/10.1155/2013/563821.

36. Pennap GR, Yakubu A, Oyige O, Forbi J. Prevelance of hepatitis B and C virus infection among people of a local community in Keffi, Nigeria. Afr. J. Microbiol. Res 2010; 4(4) :274-278.

37. Okonko IO, Okerentugba PO and Akinpelu AO. Prevelance of $\mathrm{HBsAg}$ among attendees of ARFH centre in Ibandan, Southwestern Nigeria. AmEurasian J Sci Res. 2012; 7(3):100-105.

38. Seoung-Ae L, Hong K, You-Sub W, Seung-Hyeok S, YiRang N, Han-Bo S, Kyung-Soo I, Bum-Joon K. Male-specific hepatitis $\mathrm{B}$ virus large surfaceprotein variant W4P potentiates tumorigenicity and induces gender disparity Mol. Cancer Biol. 2015; 14:23.

39. Giri PA, Deshpande JD, Phalke DB and Karle LB. Seroprevalence of Transfusion Transmissible infections among voluntary blood donars at a tertiary care teaching hospital in rural area of India. J Family Med Prim Care. 2012; 1:1.

40. Naik TB, Sathish JV, Wadekar MD. Seroprevalence of Hepatitis B Surface Antigen (HBsAg) among Patients Attending a Tertiary Care Hospital at Chamarajanagar, Karnataka, India. Int. J. 
Curr. Microbiol.App.Sci. 2018; 7(01): 1279-1284.

41. Beltagy EL, Al Balawi KE, Almuneef IAM, Memish ZA. Prervelance of hepatitis $\mathrm{B}$ virus markers among blood donors in a tertiary hospital in Tabuk, North Western Saudi Arabia. Int. J. Infect. Dis. 2008; 12: 495-499.

42. Thomas K, Thyagarajan SP, Jeyaseelan L, Varghese JC, Krishnamurthy P, Lakshmibai, et al. Community prevalence of sexually transmitted disease and human immunodeficiency virus infection in Tamilnadu, India:A probability proportional to size cluster survey. Nat Med J India. 2002;15:135-40.

43. Tankhiwale SS, Khadase RK, Jalgoankar SV. Seroprevalence of anti-HCV and hepatitis B surface antigen in HIV infected patients. Ind $\mathbf{J}$ Med Microbial. 2003;21:268-70.

44. Rogers MC, Kumarasamy N, Chaguturu SK, Flanigan TP, Mayer KH, Balakrishnan P, et al. Hepatitis B, Hepatitis C and HIV coinfection in Chennai, India. XI CROI, San Fransico, February 2004, Abstract No. 796

45. Saha MK, Chakrabarti S, Panda S, Naik TN, Manna B, Chatterjee A, et al. Prevalence of $\mathrm{HCV}$ and $\mathrm{HBV}$ infection among HIV seropositive intravenous drug users and their non-injecting wives in Manipur, India. Ind J Med Res. 2000; 111:37-9. 